\title{
Effect of Soil Compaction on Tanier Yields ${ }^{1}$
}

\author{
H. M. Lugo-Mercado, J. Badillo-Feliciano, and J. López-García
}

\begin{abstract}
Two experiments to assess the effect of soil compaction on tanier yields were established on an Oxisol (Coto clay) and on an Ultisol (Corozal clay), which were either plowed once or four times at depths of 20 or $40 \mathrm{~cm}$. An undisturbed plot was used as control. Maximum yields were obtained when the topsoil was extensively loosened. The use of a penetrometer for measuring mechanical impedance to tanier root development proved to be adequate. Resistance to penetration of the order of $25 \mathrm{~kg} \mathrm{~cm}^{-2}$ or greater, at 15 $\mathrm{cm}$ depth, reduced tanier yields considerably.
\end{abstract}

\section{INTRODUCTION}

Current high costs of fuel require a careful evaluation of all agronomic inputs in order to minimize food production costs. Land preparation is an important component of soil and crop management technology.

Tillage operations have received considerable attention during the past two decades. Encouraging results have been obtained using no tillage or minimum tillage with grain crops $(5,6,7,10)$ in the temperate zones. Abruña et al. (1) compared the effects of traditional complete land preparation vs. direct planting in undisturbed soil on yields of taniers on three tropical soils. They obtained equally high yields under both treatments.

Root growth can be restricted by soil compaction. The degree of restriction depends on physical properties of the soil such as texture, structure, and others. For example, a fine-textured soil will exhibit a lower critical bulk density (less compacted) in impeding root growth than a coarse-textured soil. The ease with which a probe can be inserted into the soil is an index commonly used for measuring mechanical impedance to root extension. Taylor and Gardner (9) found a close relationship between soil strength (measured by static penetrometer method) and root penetration. Hemsath and Mazurak (4) grew sorghum in cores of kaolinite clay and fine sand mixtures at different bulk densities. They demonstrated that penetrometer resistance to clay and sand mixtures was critical in relating physical conditions of soil to root

${ }^{1}$ Manuscript submitted to Editorial Board April 14, 1977.

${ }^{2}$ Associate Professor, Associate Agronomist, and Associate Horticulturist, respectively, Agricultural Experiment Station, Mayagüez Campus, University of Puerto Rico, Río Piedras, P.R. This research was conducted with partial financial support from the USAID 211d grant. Thanks are due to Dr. Miguel A. Lugo-López, former Soil Scientist, Agricultural Experiment Station, for his help in preparing this paper. 
growth. They did not observe root growth at a penetrometer resistance of $20 \mathrm{~kg} \mathrm{~cm}^{-2}$ or greater.

Soil compaction can affect tanier shape, size, and number of cormels per plant. It can also limit the volume of soil that roots can exploit. The objective of this study was to determine the most practical method of land preparation for taniers. In particular, an attempt was made to test frequency and depth of plowing variables at two different locations in Puerto Rico.

\section{MATERIALS AND METHODS}

\section{FIELD EXPERIMENTS}

Two soil management experiments were conducted: one at the Isabela Substation and the other at the Corozal Substation.

\section{Isabela Experiment}

This experiment was initiated in July 1973, in a Coto clay (Oxisol). This soil has been classified as a Tropeptic Haplorthox, clayey, kaolinitic isohyperthermic (8). It had a $\mathrm{pH}$ of 5.5, a CEC $\left(\mathrm{NH}_{4} \mathrm{OAc}\right)$ of 11.6 meq/100 $\mathrm{g}$ of soil in the topsoil, and the sum of exchangeable bases decreased from $6.3 \mathrm{meq}$ in the topsoil to $2.0 \mathrm{meq}$ in the subsoil. Clay content increased from $61.1 \%$ in the topsoil to $70.4 \%$ in the subsoil. Bulk density under field conditions was $1.36 \mathrm{~g} / \mathrm{cm}^{3}$. The average rainfall in the area is $1651 \mathrm{~mm}$ per year.

Treatments were as follows: Undisturbed soil; plowed to depths of 20 and $40 \mathrm{~cm}$ once in each case; plowed to depths of 20 and $40 \mathrm{~cm} 4$ times in each case; and a compacted plot. The compaction was effected by passing a $2,555 \mathrm{~kg}$ roller 4 times in a criss-cross pattern.

The plots were $6.1 \mathrm{~m} \times 5.5 \mathrm{~m}$ separated by $6.1 \mathrm{~m}$ alleys. They were arranged in a Latin square design. Rows were $91.5 \mathrm{~cm}$ apart and plants within the row were set at $60 \mathrm{~cm}$. There were 7 rows $/$ plot and 9 plants/ row. Tanier, Xanthosoma spp, cultivar Blanca del País, was used as the indicator crop. Pieces of rhizomes with at least two germinal buds, weighing 57 to $113 \mathrm{~g}$ each, were used as planting material. Before planting, the seedpieces were dipped into a fungicide solution of $5 \mathrm{~g}$ each of Dexon ${ }^{3}$ and Benlate (Benomyl) per $3.7 \mathrm{l}$ of water.

Weeds were controlled with the preemergence application of Ametryne $80 \mathrm{~W}$ at the rate of $4.48 \mathrm{~kg} / \mathrm{ha}$ in $189.5 \mathrm{l}$ of water immediately

3 Trade names are used in this publication solely for the purpose of providing specific information. Mention of a trade name does not constitute a guarantee or warranty of equipment or materials by the Agricultural Experiment Station of the University of Puerto Rico or an endorsement over other equipment or materials not mentioned. 
after planting. Subsequent weed growth was controlled by hand weeding. Fertilizer was applied 2 and 4 months after planting at the rate of $60 \mathrm{~g} / \mathrm{plant}$ in each application of the following mixture: $56 \mathrm{~kg} \mathrm{~N} / \mathrm{ha}$ as ammonium sulphate, $448 \mathrm{~kg} \mathrm{P} / \mathrm{ha}$ as triple superphosphate, $140 \mathrm{~kg} \mathrm{~K} /$ ha as chloride, and $56 \mathrm{~kg} \mathrm{Mg} / \mathrm{ha}$ as sulphate.

Rainfall was supplemented with irrigation. At harvesting, in August 1974, data from the 5 inner rows were taken on marketable yield, number of marketable tubers, plant height, and plant diameter.

\section{Corozal Experiment}

This experiment was initiated in July 1974 at the Corozal Substation in a Corozal clay (Ultisol). This soil is one of the Aquic Tropudults, clayey, mixed, isohyperthermic (8). It had a pH of 5.4, a CEC $\left(\mathrm{NH}_{4} \mathrm{OAc}\right)$ of $16.1 \mathrm{meq} / 100 \mathrm{~g}$ of soil in the topsoil, and the sum of exchangeable bases decreased from 10.4 in the topsoil to $2.1 \mathrm{meq}$ in the subsoil. Clay content increased from $46.4 \%$ in the topsoil to $66.0 \%$ in the subsoil. Bulk density was $1.43 \mathrm{~g} / \mathrm{cm}^{3}$. The average rainfall in the area is 2032 mm per year.

The treatments were as follows: Undisturbed soil; plowed to $20 \mathrm{~cm}$ depth once; plowed to $40 \mathrm{~cm}$ depth once; plowed to $20 \mathrm{~cm}$ depths 4 times; and plowed to $40 \mathrm{~cm}$ depths 4 times. In order to reach the $40 \mathrm{~cm}$ depth a subsoiler was used. Plots were $5.48 \mathrm{~m} \times 5.48 \mathrm{~m}$ with alleys of identical distances. The treatments were arranged in a randomized block design with 4 replicates. The indicator crop, fertilizer, planting distances, and data collected were identical to the Isabela experiment. This crop was harvested in July 1975.

\section{SOIL MEASUREMENTS}

At both locations, a recording penetrometer with a cone area of 0.25 square inches was employed for the study. Penetrometer resistance measurements were taken 6 months after planting and at harvesting at moisture contents ranging between 18 and $20 \%$ for the Coto soil and between 23 and 26\% for the Corozal soil. Exchangeable ions were determined by using $1 \mathrm{~N} \mathrm{NH}_{4} \mathrm{OAc}, \mathrm{pH} 7$ (2). $\mathrm{N}$ and $\mathrm{P}$ were determined by Kjeldahl distillation and Bray methods, respectively (2, 3). Bulk density was determined by obtaining the dry weight of an undisturbed soil sample taken in a cylinder of known volume.

\section{RESULTS AND DISCUSSION}

ISABELA EXPERIMENT

Yields of marketable taniers for each treatment are shown in the following tabulation and in figure 1: 


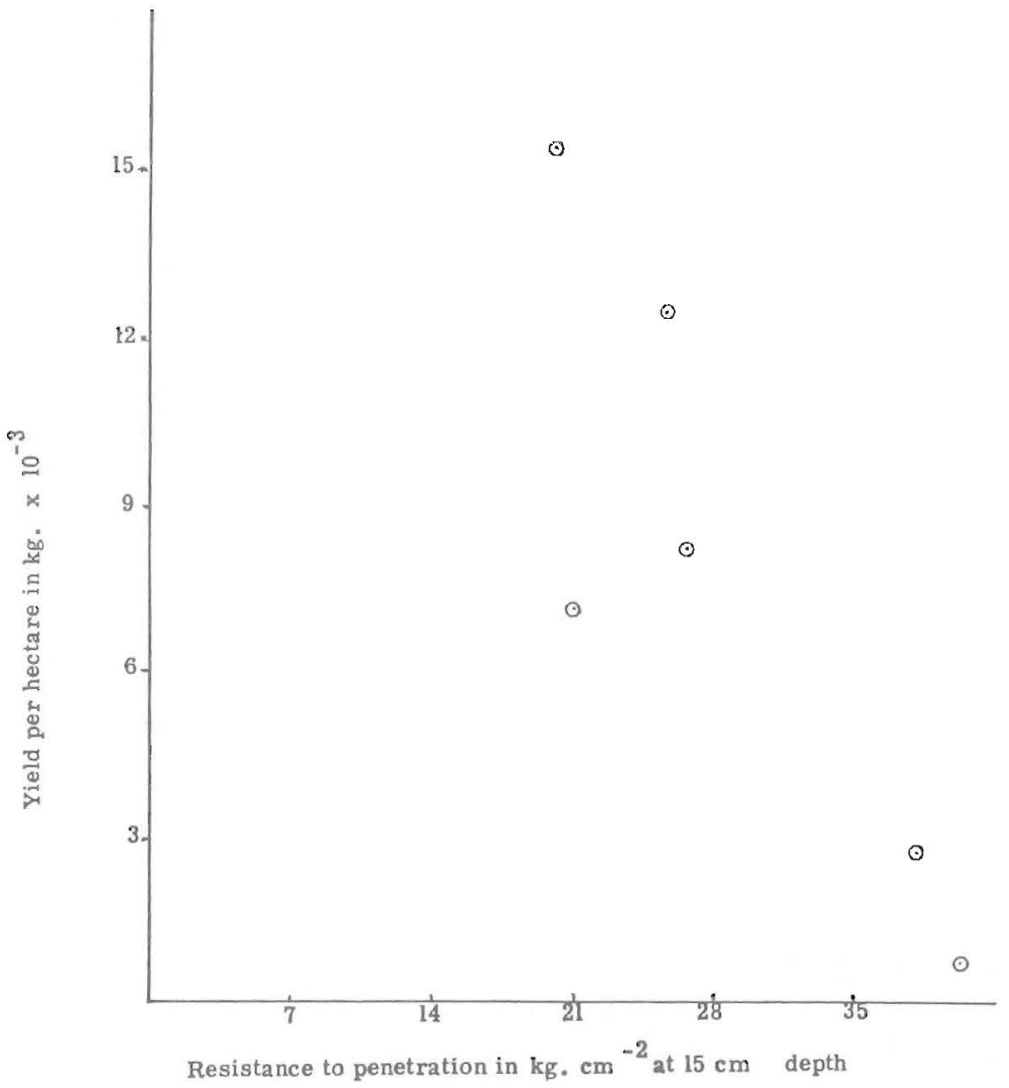

Fig. 1. - Yield of marketable taniers as affected by resistance to penetration at Isabela.

\begin{tabular}{lc}
\multicolumn{1}{c}{ Treatment } & Yield $(\mathrm{kg} / \mathrm{ha})$ \\
Undisturbed & $2,564 \mathrm{a}^{4}$ \\
Plowed once to $20 \mathrm{~cm}$ & $7,084 \mathrm{~b}$ \\
Plowed once to $40 \mathrm{~cm}$ & $8,235 \mathrm{bc}$ \\
Plowed 4 times to $20 \mathrm{~cm}$ & $15,369 \mathrm{~d}$ \\
Plowed 4 times to $40 \mathrm{~cm}$ & $12,372 \mathrm{~cd}$ \\
Compacted & $590 \mathrm{a}$
\end{tabular}

It is quite clear that taniers responded to plowing. Soil compaction reduced yields drastically. The undisturbed soil (no plowing) produced over 4 times more marketable cormels than the compacted soil. The

4 Yield values followed by one or more letters in common do not differ significantly at the $\mathrm{P}=0.05$. 
soil plowed once to 20 or $40 \mathrm{~cm}$ depth produced similar yields. These were more than twice the yields obtained from the undisturbed plots. Highest yields were obtained when the soil was plowed 4 times, either at 20 or $40 \mathrm{~cm}$ depth. The effect of the number of plowings on crop yields is noticeable. Tanier yields from the soil plowed once to $20 \mathrm{~cm}$ were less than half those from the soil plowed 4 times to the same depth $(20 \mathrm{~cm})$. Similar results were obtained when the soil was plowed to $40 \mathrm{~cm} 4$ times. The difference in yield due to plowing depth, $20 \mathrm{vs} .40$ $\mathrm{cm}$, was negligible.

Table 1 shows that there were no significant differences in soil $\mathrm{pH}$, bulk density, and levels of $\mathrm{P}, \mathrm{K}$, and $\mathrm{Ca}$, irrespective of treatment, in samples taken after harvesting. On the other hand, a correlation coefficient of -0.66 was found between the resistance to penetration at $7.5 \mathrm{~cm}$ depth and tanier yields (table 2). A similar correlation coefficient was obtained between yield and mean resistance to penetration at all depths $(7.5,15.0$, and $22.5 \mathrm{~cm})$. This is in agreement with observations from a visual inspection of the root system of selected plants from each treatment. No roots were found below $22.5 \mathrm{~cm}$ depth and most of the roots were in the 7.5 to $15 \mathrm{~cm}$ depth zone.

Figure 1 shows that there is a direct relationship between resistance to penetration at $15 \mathrm{~cm}$ depth and average tanier yield (6 replicates). Again, a similar curve was obtained when average yield was plotted against an average of the resistances to penetration at $7.5,15.0$, and $22.5 \mathrm{~cm}$ depth. This seems to indicate that for taniers grown in this soil, or on a similar one, resistance of the soil particles to be moved aside by the roots at the 7.5 to $15 \mathrm{~cm}$ depth zone is the most influential.

TABLE 1. - A comparison of some physical and chemical properties among treatments at the Isabela experimental field

\begin{tabular}{|c|c|c|c|c|c|c|c|}
\hline & \multirow{2}{*}{$\mathrm{pH}$} & \multirow{2}{*}{$\begin{array}{l}\text { Bulk } \\
\text { density }\end{array}$} & \multirow{2}{*}{$\begin{array}{l}\text { Pore } \\
\text { space }\end{array}$} & \multicolumn{4}{|c|}{ Nutrients in the soil } \\
\hline & & & & $\mathrm{N}^{1}$ & $\mathrm{Ca}^{1}$ & $\mathrm{P}^{2}$ & $\mathrm{~K}$ \\
\hline & & $\mathrm{G} / \mathrm{cm}^{3}$ & $\%$ & $\mathrm{Meq} / 100 \mathrm{~g}$ & $\mathrm{Meq} / 100 \mathrm{~g}$ & $P / m$ & $P / m$ \\
\hline Undisturbed & 5.98 & 1.29 & 51.3 & 0.20 & 5.29 & 14.6 & 34.5 \\
\hline Plowed once to $20 \mathrm{~cm}$ & 5.96 & 1.19 & 55.1 & .18 & 5.38 & 14.7 & 32.0 \\
\hline Plowed once to $40 \mathrm{~cm}$ & 5.84 & 1.22 & 54.0 & .18 & 5.01 & 15.4 & 27.0 \\
\hline $\begin{array}{l}\text { Plowed } 4 \text { times to } 20 \\
\mathrm{~cm}\end{array}$ & 6.00 & 1.24 & 53.2 & .18 & 5.37 & 14.7 & 37.2 \\
\hline $\begin{array}{l}\text { Plowed } 4 \text { times to } 40 \\
\mathrm{~cm}\end{array}$ & 6.15 & 1.04 & 60.8 & .19 & 5.29 & 17.0 & 52.0 \\
\hline \multirow[t]{2}{*}{ Compacted } & 6.08 & 1.35 & 49.1 & .17 & 5.33 & 11.6 & 35.3 \\
\hline & $\mathrm{NS}^{3}$ & NS & NS & NS & NS & NS & NS \\
\hline
\end{tabular}

${ }^{1}$ Meq per $100 \mathrm{~g}$ of dry soil.

2 Bray method.

${ }^{3}$ Not significant at the $5 \%$ level. 
A resistance to penetration of approximately $25 \mathrm{~kg} \mathrm{~cm}^{-2}$ seems to be critical, that is, tanier yields rapidly decline at measured penetrometer resistances above $25 \mathrm{~kg} \mathrm{~cm}^{-2}$.

\section{COROZAL EXPERIMENT}

The following tabulation gives yield data obtained under the conditions prevailing at Corozal:

\section{Treatment}

Undisturbed

Plowed once to $20 \mathrm{~cm}$

Plowed once to $40 \mathrm{~cm}$

Plowed 4 times to $20 \mathrm{~cm}$

Plowed 4 times to $40 \mathrm{~cm}$
Yield $(\mathrm{kg} / \mathrm{ha})$

$1,054 \mathrm{a}^{4}$

5,403 a

$14,729 \mathrm{~b}$

$11,771 \mathrm{~b}$

$14,271 \mathrm{~b}$

A significant difference was measured between treatments when the soil was plowed once to $20 \mathrm{~cm}$ and when the soil was plowed 4 times at $20 \mathrm{~cm}$ depth. When the soil was plowed to $40 \mathrm{~cm}$ depth, either once or 4 times, the highest yields were obtainned. It is apparent that plowing to a $40 \mathrm{~cm}$ depth loosened the topsoil to a degree equivalent to repeated plowing and disking (plowed 4 times). This is demonstrated by the fact that there were no significant differences between plowing to the $40 \mathrm{~cm}$ depth either 1 or 4 times and plowing 4 times to a $20 \mathrm{~cm}$ depth.

As in the Isabela Substation experiment, no significant differences were found between treatments with respect to $\mathrm{pH}$, bulk density, and nutrient content.

Table 3 shows correlation coefficients of -0.72 and -0.69 that were

TABLE 2. - Simple correlation coefficients between tanier yields and resistance to penetration at $7.5,15.0$, and $22.5 \mathrm{~cm}$ depth for the Coto soil (Isabela)

\begin{tabular}{lrrrrr}
\hline \multicolumn{1}{c}{ Variables } & \multicolumn{1}{c}{1} & 2 & 3 & 4 & 5 \\
\hline Yield & 1.00 & & & & \\
Resistance to penetration at $7.5 \mathrm{~cm}$ depth & -.66 & 1.00 & & & \\
Resistance to penetration at $15.0 \mathrm{~cm}$ depth & -.56 & .72 & 1.00 & & \\
Resistance to penetration at $22.5 \mathrm{~cm}$ depth & -.46 & .42 & .68 & 1.00 & \\
Average of variables 2,3 , and 4 & -.66 & .87 & .93 & .76 & 1.00 \\
\hline
\end{tabular}

TABLE 3. - Simple correlation coefficients between tanier yields and resistance to penetration at $7.5,15.0$, and $22.5 \mathrm{~cm}$ depth for the Corozal soil

\begin{tabular}{lrrrrr}
\hline \multicolumn{1}{c}{ Variables } & \multicolumn{1}{c}{1} & \multicolumn{1}{c}{2} & 3 & 4 & 5 \\
\hline Yield & 1.00 & & & & \\
Resistance to penetration at 7.5 cm depth & -.72 & 1.00 & & & \\
Resistance to penetration at $15.0 \mathrm{~cm}$ depth & -.69 & .86 & 1.00 & & \\
Resistance to penetration at $22.5 \mathrm{~cm}$ depth & -.60 & .71 & .93 & 1.00 & \\
Average of variables 2, 3, and 4 & -.71 & .90 & .98 & .93 & 1.00 \\
\hline
\end{tabular}




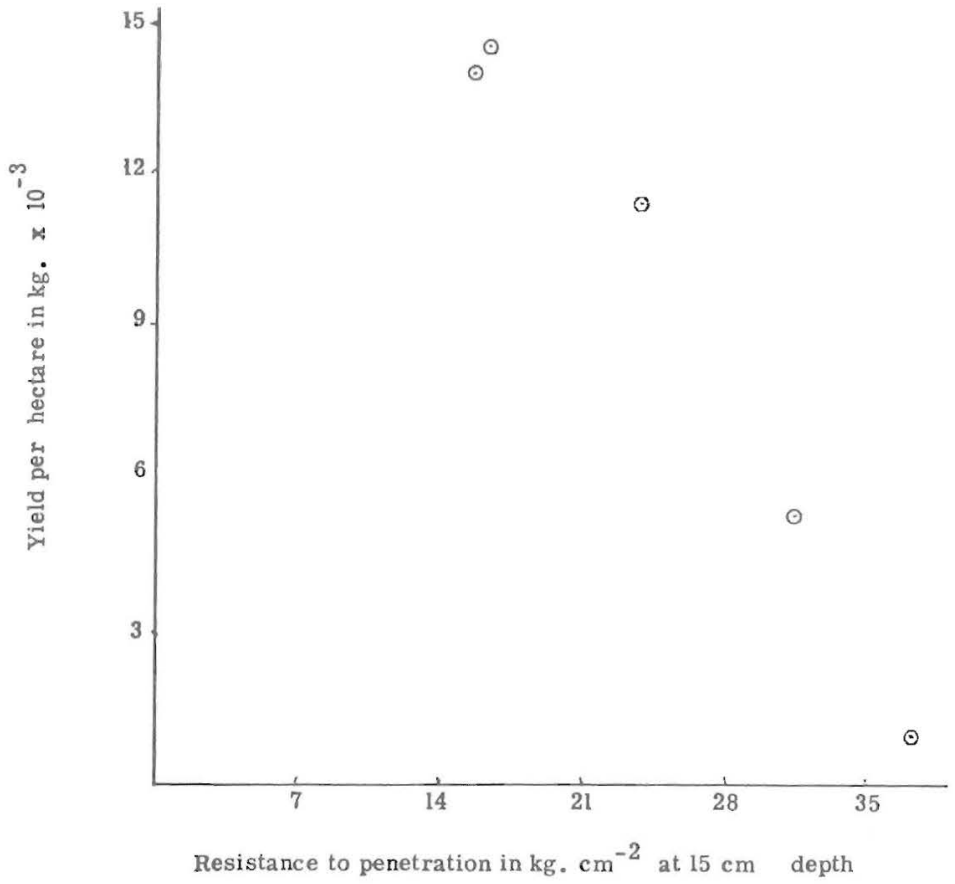

Fig. 2. - Yield of marketable taniers as affected by resistance to penetration at Corozal.

obtained between resistance to penetration at 7.5 and $15 \mathrm{~cm}$ depth and tanier yields. Figure 2 demonstrates that resistance to penetration above $25 \mathrm{~kg} \mathrm{~cm} \mathrm{~cm}^{-2}$ is detrimental to taniers under the conditions prevailing at the Corozal area.

The Corozal results, as well as those from Isabela, point to the fact that taniers are quite sensitive to soil compaction. Loosening the topsoil through repeated plowing and disking is highly recommended for Coto and Corozal soils. Soil penetrability seems to be a good indicator of the mechanical impedance of these soils to tanier root growth.

\section{RESUMEN}

Se realizaron dos experimentos para evaluar el efecto de la compactación en los suelos Coto (Oxisol) y Corozal (Ultisol) sobre los rendimientos de yautía. Se evaluó el efecto de arar una o cuatro veces a profundidades de $20 \mathrm{o} 40 \mathrm{~cm}$. Se utilizaron parcelas sin arar como control. Los rendimientos máximos se obtuvieron cuando se redujo la compactación de la capa arable. Se comprobó que el penetrómetro es un instrumento útil para medir la resistencia mecánica del suelo al crecimiento de las raíces de yautía. Resistencias a la penetración, a una profundidad de $15 \mathrm{~cm}$., de alrededor de $25 \mathrm{~kg}$. $\mathrm{cm} \cdot{ }^{-2}$ y mayores, disminuyeron considerablemente el rendimiento de la yautía. 


\section{LITERATURE CITED}

1. Abruña, F., Boneta, E. G., Vicente-Chandler, J., and Silva S., 1967, Experiments on tanier production with conservation in Puerto Rico's mountain region, $J$. Agric. Univ. P.R. 51(2): 67-75.

2. Black, C. A., Ed, 1965, Methods of soil analysis. Parts 1 and 2. Agronomy 9: 552-9, 900, 1149-76, 1374-6, Am. Soc. Agron., Madison, Wis.

3. Bray, R. H., and Kurtz, L. T., 1945, Determination of total, organic, and available forms of phosphorus in soils, Soil Sci. 59: 39-45.

4. Hemsath, D. L., and Mazurak, A. P., 1974, Seedlings growth of sorghum in claysand mixtures at various compactions and water contents, Soil Sci. Soc. Amer. Proc. 38:387-90.

5. Moschler, W. W., Martens, D. C., Rich, C. I., and Shear, G. M., 1973, Comparative lime effects on continuous no-tillage and conventionally tilled corn, Agron. J. 65: $781-3$.

6. Moschler, W. W., Martens, D. C., and Shear, G. M., 1975, Residual fertility in soil continuously field cropped to corn by conventional tillage and no-tillage methods, Agron. J. 67: 45-9.

7. Phillips, R. E., Belcher, C. R., Blevins, R. I., Miller, H. F., Thomas, G. W., Nagara, T., Quinsenberry, W., and MacMahorn, M., 1971, Agronomy Research, Univ. Ky., Misc. Publ. 394: 36-8.

8. Soil Conservation Service, USDA, 1967, Soil survey investigations Rep. No. 12. Soil survey laboratory data and descriptions for some soils of Puerto Rico and the Virgin Islands.

9. Taylor, H. M., and Gardner, H. R., 1963, Penetration of cotton seed taproots as influenced by bulk density, water content and soil strength, Soil Sci. 96: 153-6.

10. Triplett, G. B., Jr., and Van Coren, D. M., Jr., 1969, Nitrogen, phosphorus and potassium fertilization of no-tilled maize, Agron. J. 61: 637-9. 